\title{
ANTIMICROBIAL AND ANTICANCER ACTIVITY STUDIES ON GREEN SYNTHESIZED COPPER OXIDE NANOPARTICLES FROM THE MEDICINAL PLANT CYATHEA NILGIRIENSIS HOLTTUM
}

\section{PRADHEESH $\mathbf{G}^{\mathbf{1}^{*}}$, SURESH $\mathbf{J}^{2}$, SURESH $\mathbf{S}^{3}$ AND ALEXRAMANI $\mathbf{V}^{4}$}

1: Department of Chemistry, SNS College of Technology, Coimbatore - 641035, Tamil Nadu, India

2: Department of Chemistry, Sri Ramakrishna Engineering College, Coimbatore - 641022, Tamil Nadu, India

3: Department of Chemistry, National College, Trichy-620002, Tamil Nadu, India 4: Department of Chemistry, St. Joseph's College, Trichy - 620002, Tamil Nadu, India *Corresponding Author: E Mail: pradheeshchem@gmail.com; Tel.: +91-9047637329

Received 10 ${ }^{\text {th }}$ Dec. 2019; Revised $15^{\text {th }}$ Jan. 2020; Accepted $13^{\text {th }}$ Feb 2020; Available online $1^{\text {st }}$ June 2020 https://doi.org/10.31032/IJBPAS/2020/9.6.5188

ABSTRACT
The present work aims to synthesize biocompatible Copper (II) Oxide (CuO) nanoparticle using the extract of the medicinal plant Cyathea nilgiriensis Holttum. The synthesized Nanoparticle is characterized by FTIR, XRD, PSA, SEM and EDX studies. FTIR studies confirm the presence of biomolecules and metal oxide in the prepared nanoparticle. X-ray diffraction (XRD) structural analysis reveals the formation of pure hexagonal phase structures of $\mathrm{CuO}$ nanoparticles. Particle size analyzer (PSA) studies have proved that the biosynthesized $\mathrm{CuO}$ nanoparticle is below $100 \mathrm{~nm}$ in size. The surface morphology of $\mathrm{CuO}$ nanoparticles observed through Scanning electron microscope (SEM) suggests that most of the $\mathrm{CuO}$ crystallites are flower -shaped. Energy Dispersive X-Ray (EDX) analysis confirms the presence of both copper and oxygen. The possible mechanistic schemes of copper oxide nanoparticles are also predicted. The biosynthesized copper oxide nanoparticles exhibit strong antimicrobial behavior against gram positive and gram negative bacterial species and fungal species. The anticancer activity against Daltons lymphoma ascites (DLA) cells has 
been studied for the green-synthesized $\mathrm{CuO}$ nanoparticles. The anticancer activities exhibit good behavior against DLA cell lines.

Keywords: Cyathea nilgiriensis Holttum, CuO nanoparticles, green chemistry,

\section{Characterization, antimicrobial \& anticancer activity}

\section{INTRODUCTION}

An Eco-friendly biosynthesis means a method which doesn't make use of any toxic chemicals in the synthesis protocols. The synthetic methods based on naturally occurring biomaterials offer an alternative means for obtaining precisely required nano-particles. Generally, synthesis of nano-particles with controlled size and morphology is a challenging task which is highly dependent on the design of the protocols. Different feasible methodologies have been designed for the fabrication of nano-particles with unique size dependent properties. Due to the increasing environmental concerns, attempts have been routinely made to develop nanoparticle synthesis using greener synthesized nanoparticles using plant extracts over chemical synthesis routes $[\mathbf{1}, \mathbf{2}]$. Metal nanoparticles have wide range of application in areas like agriculture, energy, environment and medicine [3]. Many methods like sol-gel, precipitation-stripping, solid state reaction, alkoxide-based synthesis, sonochemical preparation, microwave irradiation and precipitation-pyrolysis are adopted to prepare $\mathrm{CuO}$ nanoparticles [4-6].
$\mathrm{CuO}$ nanoparticles are important because of their characteristics such as high- $\mathrm{T}_{\mathrm{c}}$ super conductors [7], sensors $[8,9]$ and catalysts [10]. The copper oxide nanoparticles are observed to behave as antimicrobial and antifungal agents [11]. Human beings have been using copper $(\mathrm{Cu})$ and copper complexes for various purposes for centuries, such as water purifiers, algaecides, fungicides, and as antibacterial and antifouling agents. Copper-based compounds are efficient biocidal properties, which are generally used in several health related application [12-14]. Biosynthesis of copper oxide nanoparticles using microorganisms such as bacteria, fungi, yeast have been reported in the literature [15-17]. Carcia papaya leaf extract [18], Aloe vera leaf extract [19], Centella asiatica leaf extract [20], Malva sylvestris leaf extract [21], Rosa sahandina broth extract [22] and Gloriosa superba L. plant extract [12] has attracted few researches in the synthesis of copper oxide nanoparticles. The present feasibility study is to bring out a novel green synthetic strategy to prepare $\mathrm{CuO}$ nanoparticles using Cyathea nilgiriensis plant extract focusing on the 
application in industry. Based on the literature survey it is evident that the study on the bio-synthesis and characterization of $\mathrm{CuO}$ nanoparticles using Cyathea nilgiriensis Holttum extract has been carried out for the first time. Antibacterial activities of greener synthesizes Copper oxide $(\mathrm{CuO})$ nanoparticles were tested against 3 gram positive $(S$. aureus, B. subtilis \& M. luteus) and 3 gram negative (E. coli, S. paratyphi \& $K$. pneumonia) bacteria using disc diffusion method. Similarly, the antifungal analysis has been done against 2 strains namely $C$. albicans and $A$. niger. The anticancer activity of biosynthesized Copper oxide $(\mathrm{CuO})$ nano particles were also carried out by tryphan blue assay method using Daltons lymphoma ascites (DLA) bearing mice.

\section{MATERIALS AND METHODS}

\subsection{Plant materials collection and preparation}

The pure and analar - grade Copper nitrate $\left[\mathrm{Cu}\left(\mathrm{NO}_{3}\right)_{2} .9 \mathrm{H}_{2} \mathrm{O}\right]$ was used for this study. The pure and shade-dried leaves of Cyathea nilgiriensis (2 g) were powdered and subjected to extraction using deionized water. The extract obtained was filtered through Whatman No. 1 filter paper and stored in a refrigerator for further use.

\subsection{Synthesis of $\mathrm{CuO}$ nanoparticles}

A stock solution of $0.1 \mathrm{M}$
$\mathrm{Cu}\left(\mathrm{NO}_{3}\right)_{2} .9 \mathrm{H}_{2} \mathrm{O}$ was prepared. $50 \mathrm{ml}$ of 0.1 $\mathrm{M}$ copper nitrate solution was taken in a beaker then $10 \mathrm{~mL}$ of Cyathea nilgiriensis aqueous extract was added drop wise into the solution under magnetic stirring at $80^{\circ} \mathrm{C}$ for 4 hours. The complex formed was ultra-centrifuged at 10,000 rpm for $10 \mathrm{~min}$. The complex residue was rinsed with water and centrifuged again at 5,000 rpm for $10 \mathrm{~min}$. The complex residue was dried in an oven at $40{ }^{\circ} \mathrm{C}$ for $8 \mathrm{~h}$ and was then calcined in a muffle furnace at $450{ }^{\circ} \mathrm{C}$ to obtain biosynthesized $\mathrm{CuO}$ nanoparticles. 2.3. Instrumentation (PSA, FT-IR, XRD and SEM-EDX)

Nanoparticles size was confirmed by using particle size analyzer (Nanophox, Sympatec, Germany). The biosynthesized $\mathrm{CuO}$ nanoparticles were analyzed for IR characteristics using a Nicolet 520P FT-IR spectrometer set to be in the range of $500-$ $4,000 \mathrm{~cm}^{-1}$. A powder XRD analysis was carried out on a PAN analytical X-ray diffractometer operated at $40 \mathrm{kV}$ with a current of $30 \mathrm{~mA}$ under $\mathrm{Cu}-\mathrm{K}_{\alpha}$ radiation of a $2 \theta$ range of $10-80^{\circ}$. The SEM images were recorded using a JEOL JSM 6390 system. An energy dispersive X -ray spectroscopic (JED 2300, JEOL) study was done on $\mathrm{CuO}$ nanoparticles to confirm the presence of the constituent elements copper and oxygen. 


\subsection{Antimicrobial activity}

The antimicrobial activity was studied applying the disc diffusion method [23]. Ciprofloxacin and fluconazole were taken as a standard for antimicrobial activity. A panel of 6 common pathogenic bacteria consisting of three gram-positive type aureus (NCIM 2079), B. subtilis (NCIM 2063), M. luteus (MCIM2169) and three gram negative type E. coli (NCIM 2065), S. paratyphi (NCIM 2501), K. pneumoniae (NCIM2707) and 2 fungal strains $C$. albicans (MTCC 3100) and A.niger (MTCC 1344) was used. These microbial strains were obtained from the Kovai Medical College and Hospital $(\mathrm{KMCH})$, Coimbatore, Tamil Nadu, India.

\subsection{Anticancer activity}

Trypan blue dye assay method [24, 25] was carried out to evaluate the in vitro cytotoxicity potentials biosynthesized $\mathrm{CuO}$ nanoparticles. The cells were aspirated from the peritoneal cavity of tumor bearing mice. The cells were washed three times using PBS and the viability of the cells was checked using trypan blue. Different concentrations $(10,20,50,100$ and $200 \mu \mathrm{g})$ of $\mathrm{CuO}$ nanoparticles were prepared. In a test tube, $100 \mu \mathrm{l}$ of $\mathrm{CuO}$ nanoparticles was mixed with $800 \mu l$ of phosphate buffer saline and $100 \mu \mathrm{l}\left(1 \times 10^{6} \mathrm{in} 1 \mathrm{ml}\right)$ of Dalton's Lymphoma Ascites (DLA) was added. All the test tubes were incubated at $37^{\circ} \mathrm{C}$ in an incubator for 3 hours. About $100 \mu 1$ of trypan blue dye was added to all the test tubes. Dead cells took on a trypan blue color while live cells did not absorb the dye. The number of stained and unstained cells was measured using hemocytometer. Percentage of cytotoxicity was calculated by the following formula.

$$
\text { Gytotoxicity }(\%)=\frac{N_{d}}{N_{d}+N_{\mathbb{d}}} \times 100
$$

Where, $N_{d}$ - No of dead cells, $N_{l}$ - No of live cells

\section{RESULTS AND DISCUSSION}

\subsection{Synthesis mechanisms of copper oxide nanoparticles}

Figure 1 shows the possible mechanism for the formation of copper oxide nanoparticles. Preliminary phytochemical analysis of C. nilgiriensis ethanol extracts confirmed the presence of Tannin, Saponnin, Flavonoids, Steroids, Terpenoids, Triterpenoids, Carbohydrate, Protein, Anthroquinone, Polyphenol, Glycoside and Coumarine. The flavonoid type of compounds could have formed complex with copper (II) ion of copper Nitrate solution. The complex solution was then heated in hot air oven for 8 hours to form copper hydroxide further it was calcinated at $450^{\circ} \mathrm{C}$ to form copper oxide nanoparticles.

\subsection{Particle Size Analyzer}

The average size of the $\mathrm{CuO}$ 
nanoparticles and the statistical distribution of the size were determined using the particle size analyzer. The particle size of Copper oxide nanoparticles is found to be below $100 \mathrm{~nm}$. The results are shown in

\section{Figure 2.}

\subsection{FT-IR spectral study}

Figure 3 Shows the FT-IR spectrum of bio-synthesized copper oxide nanoparticles. Copper Oxide absorbs IR radiation at $513.09 \mathrm{~cm}^{-1}$. The $\mathrm{O}-\mathrm{H}$ stretch appears in the spectrum at $3449.84 \mathrm{~cm}^{-1}$. The absorption in the region $1632.81 \mathrm{~cm}^{-1}$ indicates the presence of aromatic ring. The absorption peak at $1113.94 \mathrm{~cm} 1$ corresponds to $\mathrm{C}-\mathrm{O}$ stretching of saturated primary alcohol. The band $1632.81 \mathrm{~cm}-1$ corresponds to the carbonyl group of flavonoids. The results of FTIR analysis indicated that phenolic type of compound would have a stronger binding force towards the metal, favoring the formation of metal nanoparticles and minimizing the agglomeration. This suggests that the phenolic type of biological molecules could do dual functions of formation and stabilization of copper oxide nanoparticles in aqueous medium.

\subsection{X-ray diffractometer}

Figure 4 shows the X-ray diffractometer (XRD) spectrum of the biosynthesized copper oxide nanoparticles. The main peaks found correspond to Bragg reflections with $2 \theta$ values of $32.49^{\circ}, 35.52^{\circ}$ $38.71^{\circ}, 46.30^{\circ}, 48.80^{\circ}, 53.36^{\circ}, 58.20^{\circ}$, $61.52^{\circ}, \quad 66.21^{\circ}, \quad 67.87^{\circ}, \quad 72.30^{\circ}$, $75.05^{\circ}, 80.46,82.52^{\circ}$ and $86.95^{\circ}$. Locations of the characteristic Bragg reflections were indexed to (1 10$),(-111),\left(\begin{array}{lll}1 & 1 & 1\end{array}\right),\left(\begin{array}{lll}-1 & 0 & 0\end{array}\right)$,

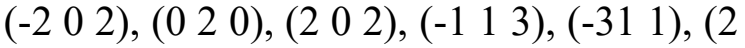
2 0), (311), (-2 22 2), (-3 113$),\left(\begin{array}{lll}2 & 2 & 2\end{array}\right)$ and (1 3 0) planes of $\mathrm{CuO}$ monoclinic phase structures, respectively (standard JCPDS card 01-080-1916) and this confirms the presence of copper oxide nanoparticles. The XRD pattern observed confirms the absence of other impurities. Table 1 shows the calculated crystallite sizes and lattice strain values for $\mathrm{CuO}$ nanoparticles found based on Debye Scherer's formula, which is given below.

$$
D=0.94 \lambda / B \operatorname{Cos} \theta
$$

Where $\mathrm{D}$ is the average crystallite size, where $\beta$ denotes line broadening in radians, where $\theta$ is the Bragg angle, and where $\lambda$ is the X-ray wavelength. The average crystallite size observed from the intense plane of $\left(\begin{array}{lll}-1 & 1 & 1\end{array}\right)$ was measured as $29.05 \mathrm{~nm}$. XRD patterns obtained through this study are similar to XRD patterns obtained for biologically synthesized $\mathrm{CuO}$ nanoparticles [26].

\subsection{SEM and EDX analyses}

Raja Naika and colleagues found a spherical shaped nanoparticle with a diameter range of 5-10 $\mathrm{nm}$ in Gloriosa 
superba L. plant extract [27]. Figure 5 a, b, c \& d shows SEM and EDX images of biosynthesized copper oxide nanoparticles. The SEM images show agglomerations of individual copper oxide particles. A closer look at the agglomerated lump shows the presence of several nanoparticle aggregates. In Figure 5 (a), particles appear to be agglomerated and some individual crystals are clearly visible. In Figure 5 (b) \& (c) some particles appear to be in flower shaped. The EDX results shown in Figure 5(d) further confirm the presence of both copper and oxygen in copper oxide nanoparticles without any impurities.

\subsection{Antimicrobial activity of $\mathrm{CuO}$ nanoparticles}

H. Raja Naika et al. [12] found significant antibacterial activity in $\mathrm{CuO}$ nanoparticles synthesized from Gloriosa superba L extract against pathogenic bacterial strains Gram negative (Klebsiella aerogenes, Pseudomonas desmolyticum, and Escherichia coli) and Gram positive bacteria (Staphylococcus aureus). Similarly, $\mathrm{CuO}$ nanoparticles synthesized Ocimum basilicum plant leaf extracts exhibited good antibacterial behavior against pathogenic bacterial strains E. coli and S. aureus [27]. Faheem Ijaz et al. [28] found good antibacterial activity for $\mathrm{CuO}$ nanoparticles synthesized from Abutilon indicum against the bacterial species such as Klebsiella and Bacillus subtilis. In this study we explored antimicrobial activity of $\mathrm{CuO}$ nanoparticles synthesized using medicinal plant Cyathea nilgiriensis leaf extract. $\mathrm{CuO}$ nanoparticles exhibit antimicrobial efficiency due to the factors such as particle size and surface morphology.

We also found biosynthesized $\mathrm{CuO}$ nanoparticles obtained from Cyathea nilgiriensis plant extract to exhibit good antibacterial behavior. Figure 6 shows the antibacterial activity of the biosynthesized $\mathrm{CuO}$ nanoparticles. Antibacterial activity was measured against three grams of positive bacteria (S. aureus, B. subtilis, M. luteus) and three gram of negative bacteria (E. coli, $S$. paratyphi, K. pneumoniae). Antifungal activity was carried out against $C$. albicans and $A$. niger, Ciprofloxacin is taken as the standard for all microbial strains.

Table 2 shows inhibition results obtained for the $\mathrm{CuO}$ nanoparticles. The zone of inhibition for standard ciprofloxacin for three gram positive bacteria was found to be $34 \mathrm{~mm}$ (S. aureus), $27 \mathrm{~mm}$ (B. subtilis) and $36 \mathrm{~mm}$ (M. luteus). The zones of inhibition of $\mathrm{CuO}$ nanoparticles for three gram positive bacteria are found to be 20 $\mathrm{mm}$ (S. aureus), $17 \mathrm{~mm}$ (B. subtilis) and 21 mm M. luteus. When we compare the zone of inhibition of three gram positive bacteria, M. luteus $(21 \mathrm{~mm})$ shows a larger 
zone of inhibition. The zone of inhibition for standard ciprofloxacin for three gram negative bacteria ranges from $36 \mathrm{~mm}(E$ coli), $35 \mathrm{~mm}$ (S. paratyphi) and $32 \mathrm{~mm}$ (K. pneumoniae). The zones of inhibition $\mathrm{CuO}$ nanoparticles for three gram negative bacteria are found to be $20 \mathrm{~mm}$ (E coli), 16 $\mathrm{mm}$ (S. paratyphi) and $19 \mathrm{~mm}$ (K. pneumoniae). On comparing the zone inhibition values for three gram negative bacterial species E. coli $(20 \mathrm{~mm})$ shows a larger zone of inhibition. This superior activity against bacterial species was due to the fact that the copper ions released form $\mathrm{CuO}$ nanoparticles permeated the bacterial cell membrane and destroyed the structure of the cell membrane by attaching to the negatively charged cell wall $[\mathbf{2 9}, \mathbf{1 8}]$. Copper ions are involved in cross-linkage of nucleic acid strands by binding them with DNA molecule of bacteria. This results in a disordered helical structure of DNA molecule which causes denaturation of proteins and some other biochemical processes in the cell, leading to complete destruction of the bacterial cell [30].

Table 3 shows antifungal results for the biosynthesized $\mathrm{CuO}$ nanoparticles. Figure 7 shows antifungal images of the $\mathrm{CuO}$ nanoparticles. The zone of inhibition for the standard Ciprofloxacin of two fungal species are found to be $C$. albicans $(35 \mathrm{~mm})$ and $A$. niger $(09 \mathrm{~mm})$. C.albicans $(24 \mathrm{~mm})$ presents a larger zone of inhibition compared to that of $A$. niger $(10 \mathrm{~mm})$ for the biosynthesized $\mathrm{CuO}$ nanoparticles. Antifungal activity is likely derived through electrostatic attraction between the negatively charged cell membranes of microorganisms and the positively charged nanoparticles [31, 32]. The biosynthesized copper oxide nanoparticle synthesized using Cyathea nilgiriensis Holttum leaf extracts has effective inhibition against the fungal species. Thus, nanoparticles can be used as antifungal agents and can help to overcome hurdles of fungal diseases in human beings.

\subsection{Anticancer activity}

The potential anticancer activity of silver nanoparticles synthesized using different plant extracts had been reported in literature $[33,34]$. In this work the focus was on $\mathrm{CuO}$ nanoparticles synthesis using Cyathea nilgiriensis Holttum leaf extract and their potential anticancer behavior against the mice cell lines. Figure 8 [af] shows anticancer images of $\mathrm{CuO}$ nanoparticles at different concentrations. DLA (Daltons lymphoma ascites) bearing mice cell lines was used for determining cancer activity based on different concentrations $(10,20,50,100$ and $200 \mu \mathrm{g})$ of $\mathrm{CuO}$ nanoparticles. The cyclophosphamide drug is taken as a standard for the DLA cell line. Figure 8a shows a control 
image and there is no inhibition here. inhibition rate for $\mathrm{CuO}$ nanoparticles. In However, in Figure 8 [b-f] clearly shows this work we found biosynthesized $\mathrm{CuO}$ that $\mathrm{CuO}$ nanoparticles have increasing nanoparticles exhibit strong anticancer percentage of inhibition over higher concentration of the test sample. At activity. Table 4 shows the anticancer $200 \mu \mathrm{g} / \mathrm{ml}$ we observed the maximum activity results of $\mathrm{CuO}$ nanoparticles.

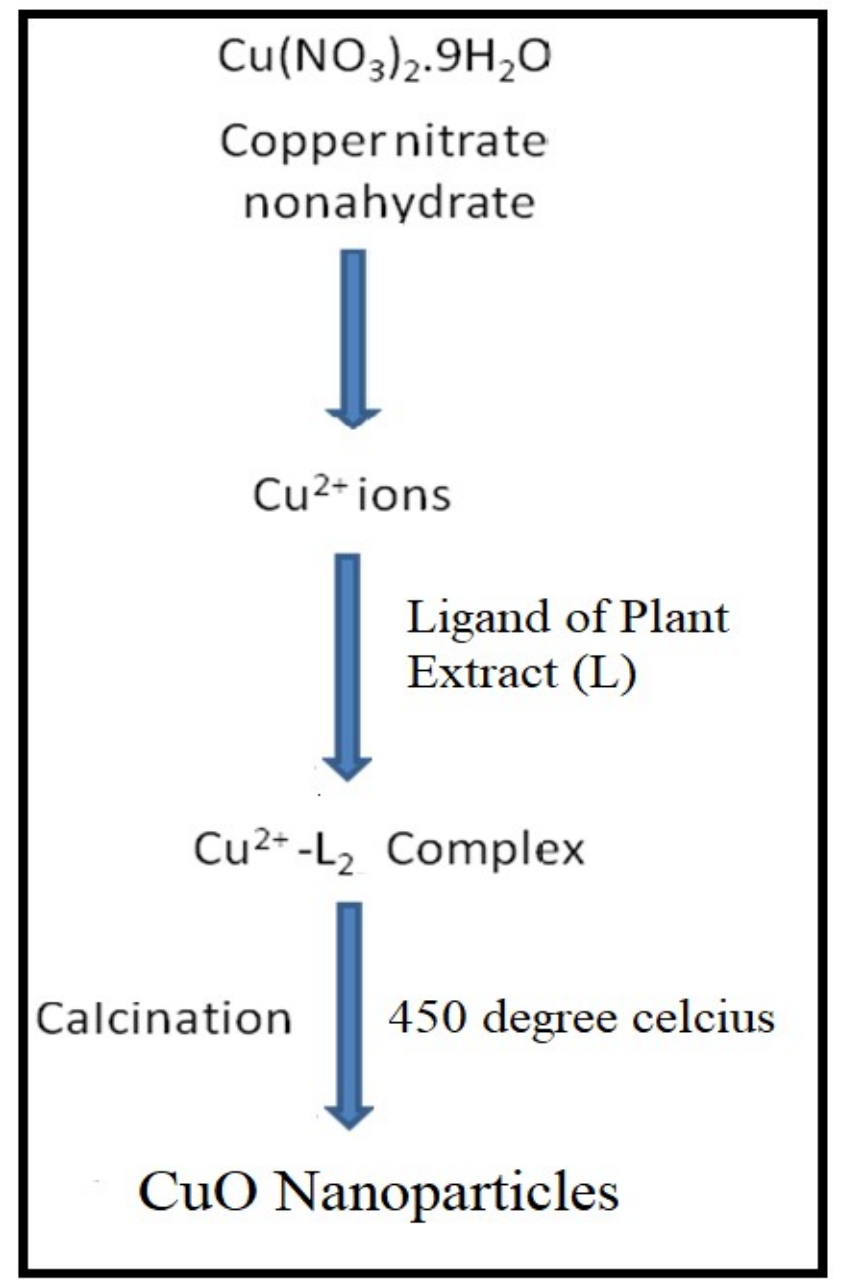

Figure 1: Scheme of $\mathrm{CuO}$ Nanoparticle synthesis 


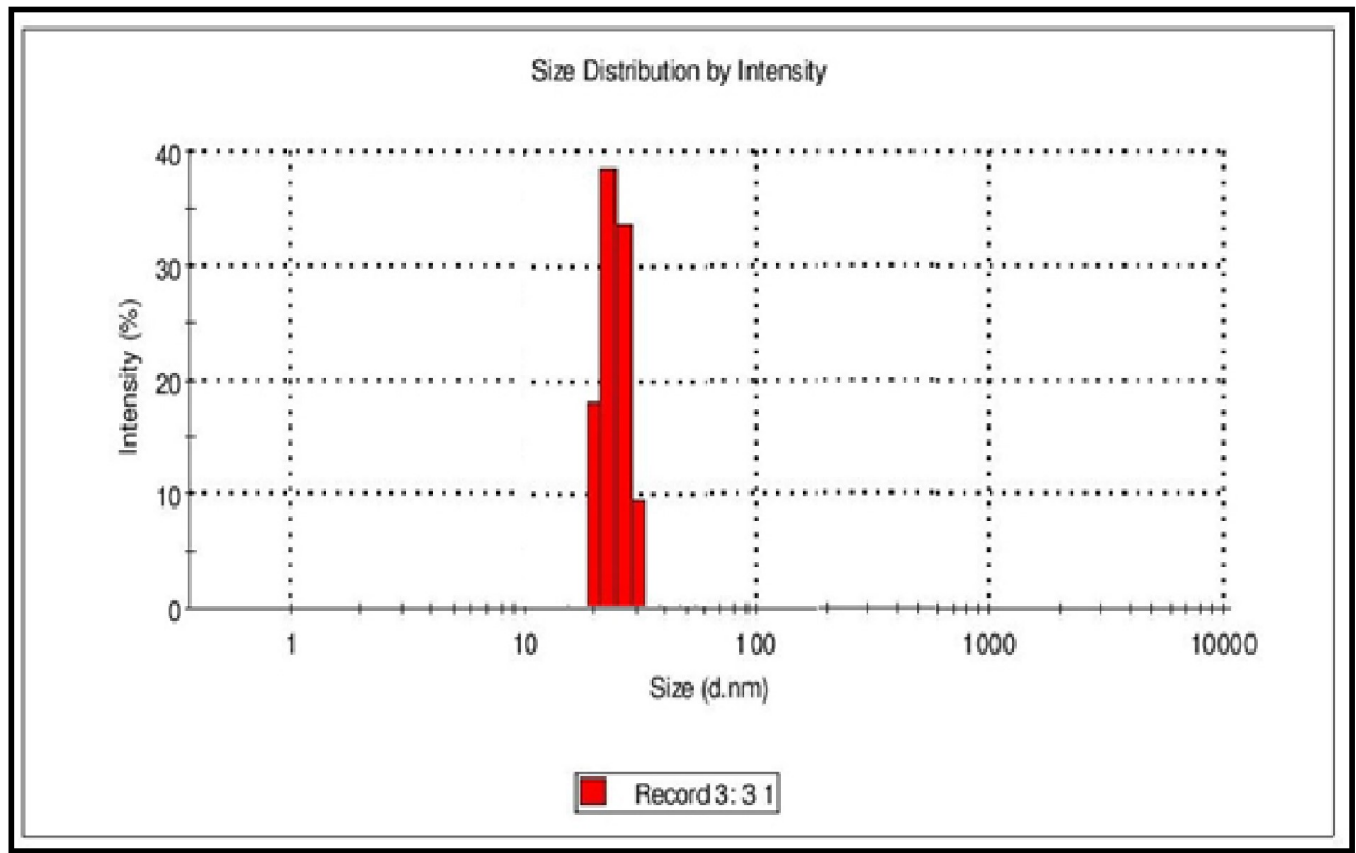

Figure 2: PSA image of $\mathrm{CuO}$ nanoparticles

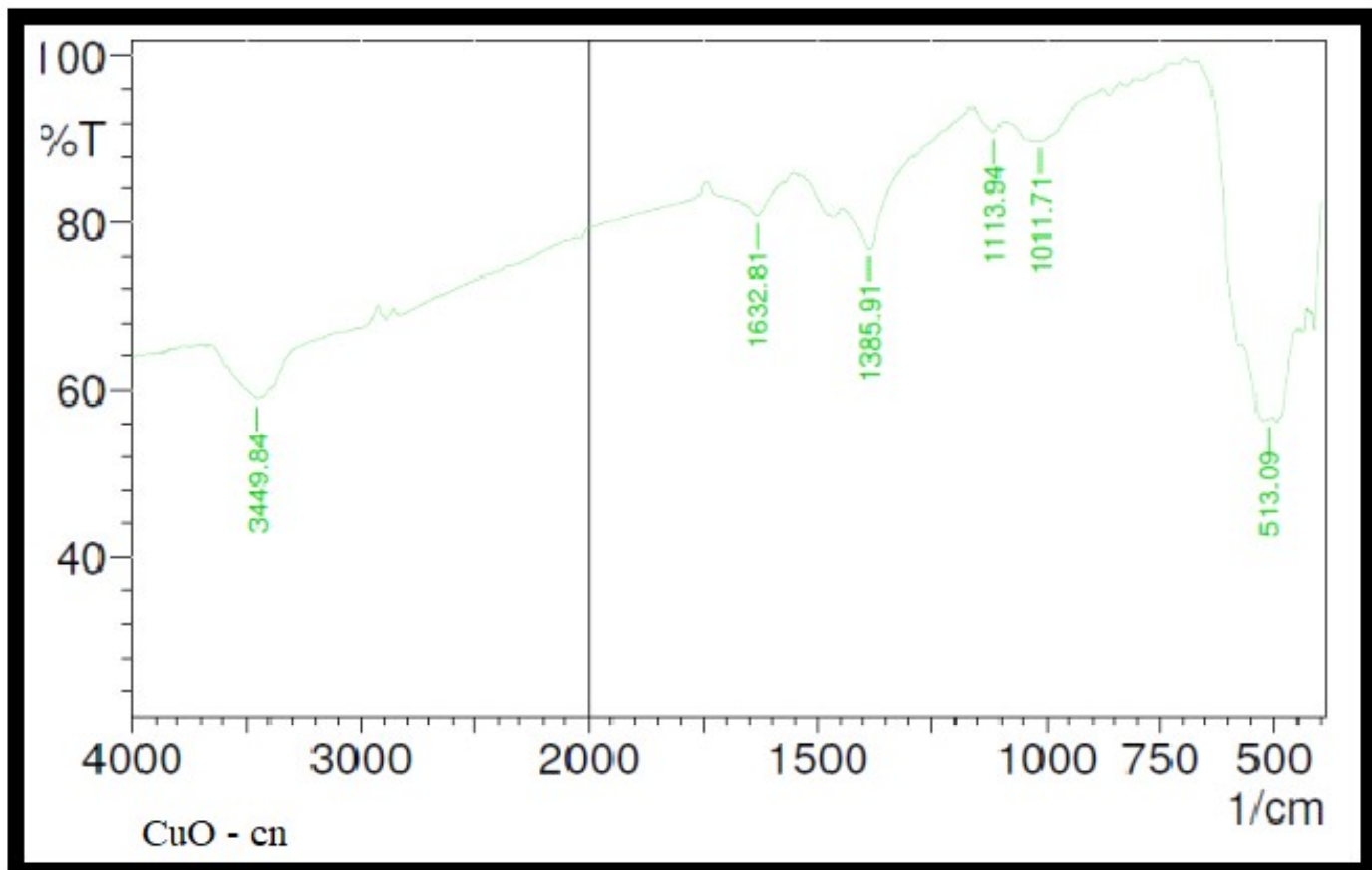

Figure 3: FT-IR spectra of $\mathrm{CuO}$ nanoparticle 


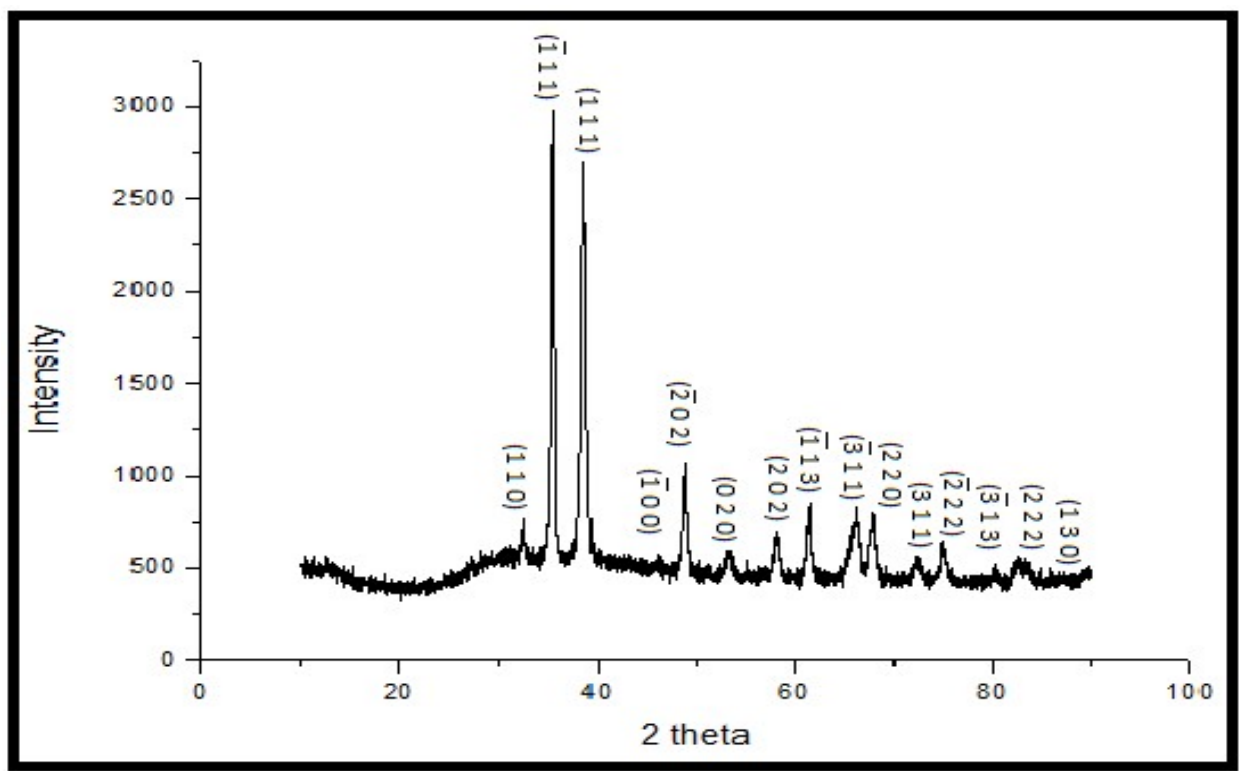

Figure 4: XRD spectra of $\mathrm{CuO}$ nanoparticle

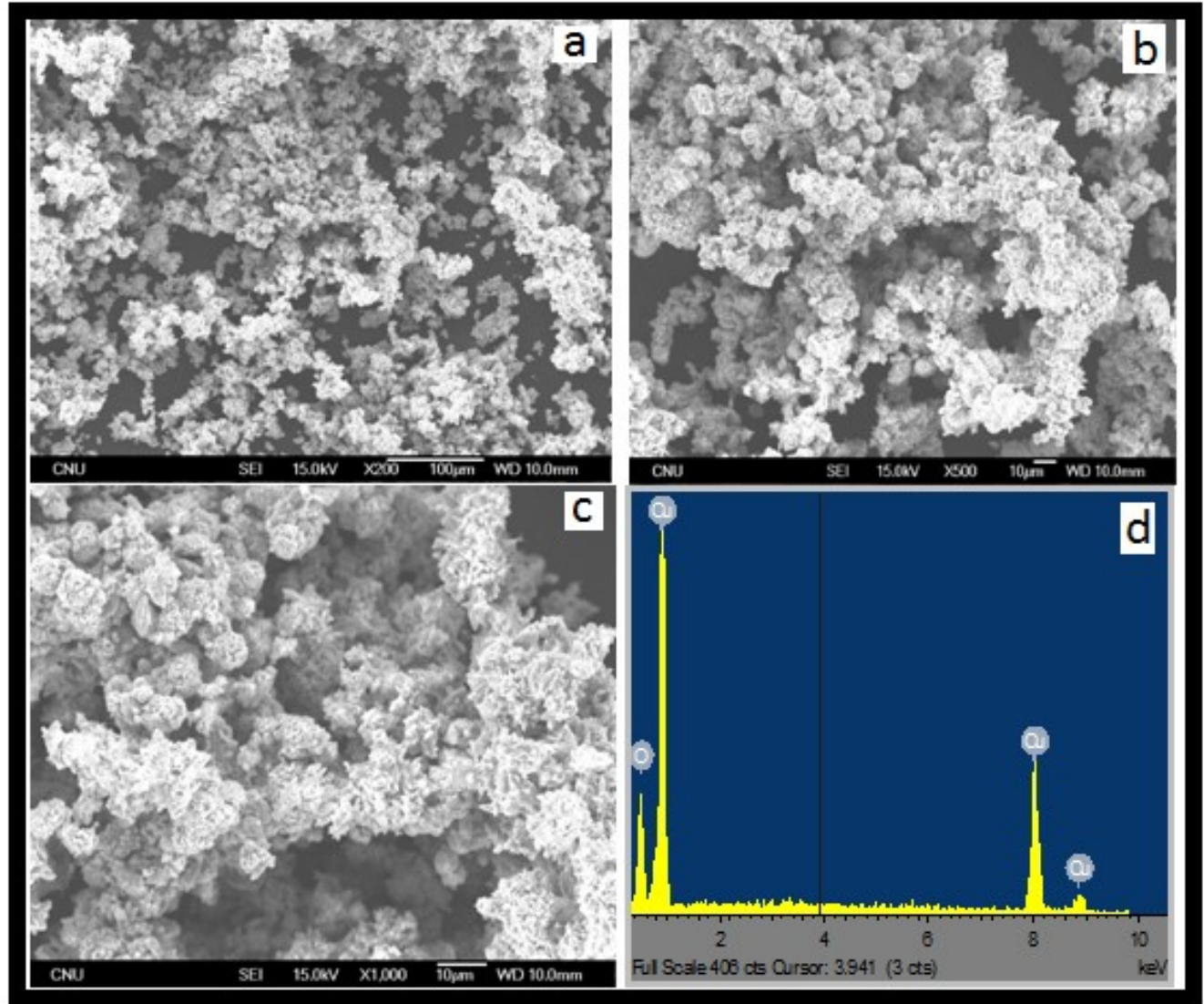

Figure 5: SEM (a, b \& c) \& EDX (d) spectra of CuO nanoparticles 


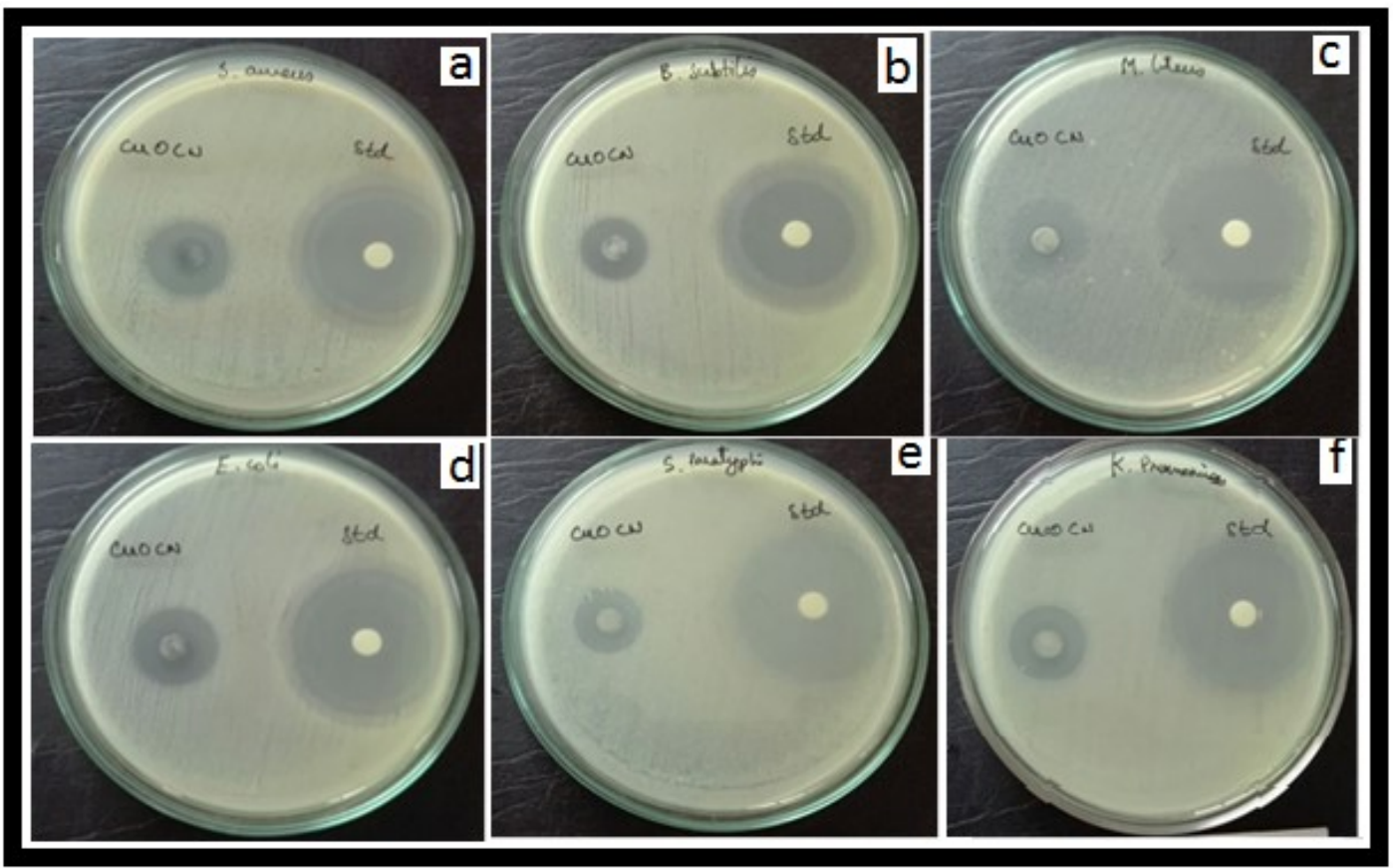

Figure 6: Antibacterial images of $\mathrm{CuO}$ nanoparticles a) S. aureus, b) B.subtilis, c) M.luteus d) E. coli e) S.paratyphi f) K.pneumoniae

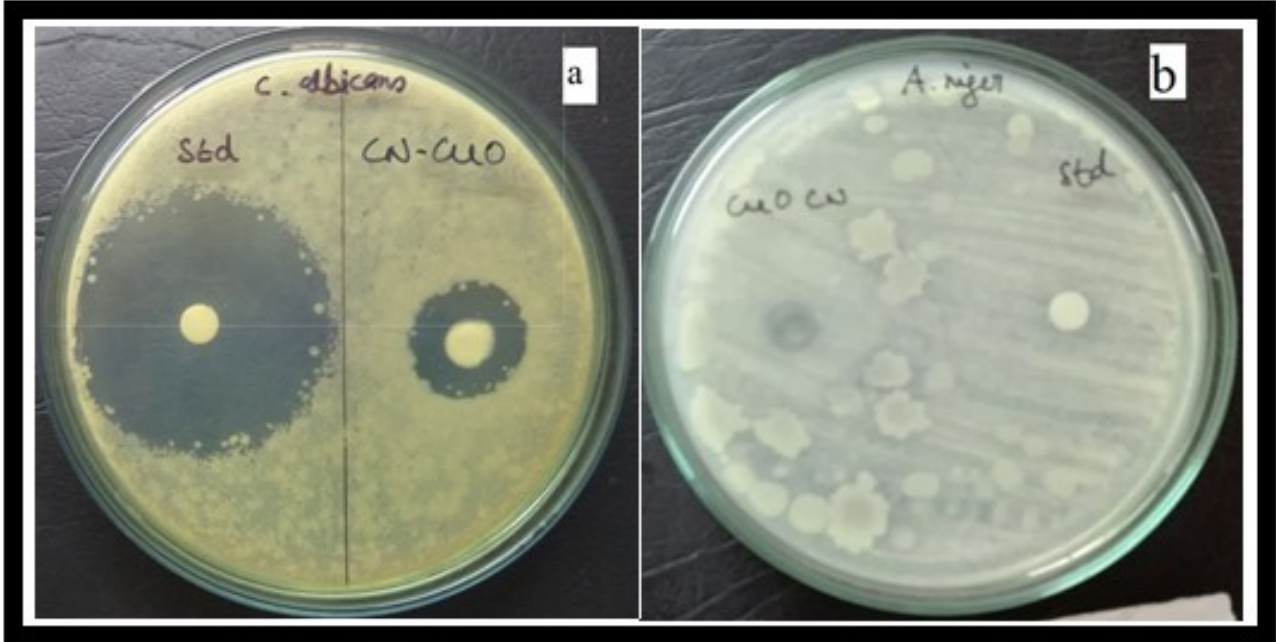

Figure 7: Antifungal images of $\mathrm{CuO}$ nanoparticles a) C.albicans b) A.niger 


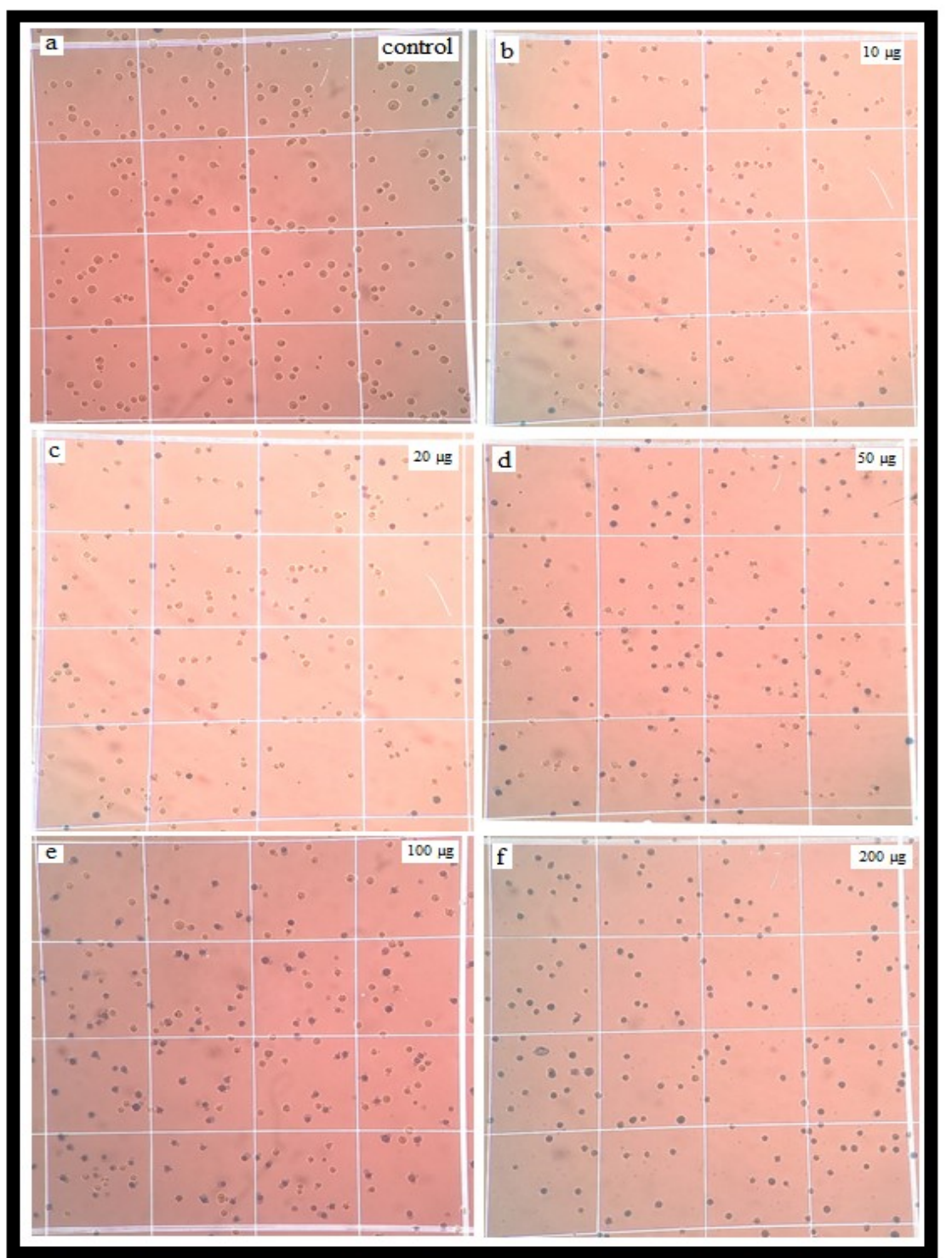

Figure 8: Anticancer activity of $\mathrm{CuO}$ nanoparticles a) Control b) $10 \mu \mathrm{g}$ c) $20 \mu \mathrm{g}$ d) $50 \mu \mathrm{g}$ e) $100 \mu \mathrm{g}$ f) $200 \mu \mathrm{g}$

Table 1: XRD Values of $\mathrm{CuO}$ nanoparticles

\begin{tabular}{|c|c|c|}
\hline 2 theta & Crystallite size (nm) & Lattice strain \\
\hline 32.49 & $28.82(110)$ & 0.0045 \\
\hline 35.52 & $29.05(-111)$ & 0.0041 \\
\hline 38.71 & $29.33(111)$ & 0.0037 \\
\hline 46.30 & $30.08(-100)$ & 0.0031 \\
\hline 48.80 & $30.38(-202)$ & 0.0029 \\
\hline 53.36 & $30.96(020)$ & 0.0026 \\
\hline 58.20 & $31.66(202)$ & 0.0024 \\
\hline 61.52 & $32.20(-113)$ & 0.0022 \\
\hline 66.21 & $33.03(-311)$ & 0.0020 \\
\hline 67.87 & $33.35(220)$ & 0.0019 \\
\hline 72.30 & $34.26(311)$ & 0.0018 \\
\hline 75.05 & $34.88(-222)$ & 0.0017 \\
\hline 80.46 & $36.23(-313)$ & 0.0015 \\
\hline 82.52 & $36.80(222)$ & 0.0015 \\
\hline 86.95 & $38.12(130)$ & 0.0014 \\
\hline
\end{tabular}


Table 2: Zone inhibition values of gram positive and gram negative bacterias

\begin{tabular}{|c|c|c|}
\hline \multirow{3}{*}{ Name of organisms } & \multicolumn{2}{|c|}{ Zone of Inhibition (mm) } \\
\hline & \multirow{2}{*}{\begin{tabular}{l}
\multicolumn{1}{c}{ Std } \\
Ciprofloxacin \\
$(10 \mu \mathrm{g} / \mathrm{disc})$ \\
\end{tabular}} & $\begin{array}{c}\text { Samples } \\
(100 \mu \mathrm{g} / \mathrm{disc})\end{array}$ \\
\hline & & $\mathrm{CN}-\mathrm{CuO}$ \\
\hline S. aureus & 34 & 20 \\
\hline B. subtilis & 27 & 17 \\
\hline M. luteus & 36 & 21 \\
\hline E. coli & 36 & 20 \\
\hline S. paratyphi & 35 & 16 \\
\hline K.pneumoniae & 32 & 19 \\
\hline
\end{tabular}

Table 3: Zone inhibition values of fungal species

\begin{tabular}{|c|c|c|}
\hline \multirow{2}{*}{ Name of organisms } & \multicolumn{2}{|c|}{ Zone of Inhibition (mm) } \\
\cline { 2 - 3 } & $\begin{array}{c}\text { Std } \\
\text { Ciprofloxacin } \\
(10 \mu \mathrm{g} / \text { disc })\end{array}$ & $\begin{array}{c}\text { Samples } \\
(100 \mu \mathrm{g} / \text { disc })\end{array}$ \\
\cline { 2 - 3 } & 09 & $\mathbf{C N}-\mathrm{CuO}$ \\
\hline A.niger & 35 & 10 \\
\hline C.albicans & & 24 \\
\hline
\end{tabular}

Table 4: Anticancer activity results of $\mathrm{CuO}$ nanoparticles

\begin{tabular}{|c|c|c|c|c|c|c|c|c|}
\hline Cell line & \multicolumn{2}{|c|}{ Name of sample } & \multicolumn{5}{|c|}{ Anticancer Results } \\
\hline DLA & $\begin{array}{c}\text { CuO } \\
\text { nanoparticles }\end{array}$ & $\begin{array}{c}\text { Concentration } \\
\mu \mathrm{g} / \mathrm{ml}\end{array}$ & Control & 10 & $\mathbf{2 0}$ & $\mathbf{5 0}$ & $\mathbf{1 0 0}$ & $\mathbf{2 0 0}$ \\
\cline { 2 - 8 } & $\begin{array}{c}\% \text { of } \\
\text { inhibition }\end{array}$ & 100 & 20 & 35 & 70 & 82 & 100 \\
\hline
\end{tabular}

\section{CONCLUSIONS}

The biocompatible synthesis of copper oxide nanoparticles $(\mathrm{CuO})$ was achieved by applying a simple and novel green chemistry procedure involving the use of Cyathea nilgiriensis Holttum leaf extract as a reducing and capping agent. The biosynthesis of $\mathrm{CuO}$ nanoparticles was carried out via hydroxide precipitation at room temperature followed by calcination at $450^{\circ} \mathrm{C}$. The successful formation of copper oxide nanoparticles was confirmed by PSA, FTIR, XRD, SEM and EDX analyses. XRD results confirms the average crystallite size observed from the intense plane (101) was measured
29.11
The biosynthesized $\mathrm{CuO}$ nanoparticles exhibited strong levels of antibacterial activity against M. luteus (Grampositive bacteria) and E. coli (Gramnegative bacteria). C.albicans exhibited stronger antifungal behavior than the $\mathrm{C}$. albicans strain. Biosynthesized $\mathrm{CuO}$ nanoparticles were found to protect against bacterial and fungal pathogens, suggesting that they may be used as effective antimicrobial and anticancer agents for commercial biomedical applications.

\section{ACKNOWLEDGMENT}

The authors are extremely grateful to the SNS college of technology, Coimbatore, TamilNadu, India for providing financial support (faculty 
research seed money) and research facilities to accomplish this study.

\section{CONFLICTS OF INTEREST}

The authors declare no conflicts of interest.

\section{REFERENCES}

[1] Iravani S. Green Synthesis of Metal Nanoparticles Using Plants, Green Chemistry, 13, 2014, 2638-2650.

[2] Susan A, Mansor B A, Farideh N, R osfarizan M, Biosynthesis of Silver Nanoparticles Using Brown Marin e Macroalga, Sargassum Muticum Aqueous Extract, Material letter, 6, 2013, 5942-5950.

[3] Chandran S P, Chaudhary M, Pasricha R, Ahamed A, Sastry M, Synthesis of Gold Nanotriangles and Silver Nanoparticles Using Aloe vera Plant Extract, Biotechnology Progress, 22, 2006, 577-583.

[4] Pike J, Chan SW, Zhang F, Wang X, Hanson J, Formation of stable $\mathrm{Cu}_{2} \mathrm{O}$ from reduction of $\mathrm{CuO}$ nanoparticles, Applied Catalysis A, 303, 2006, 273-277.

[5] Zhou K, Wang R, Xu B, Li Y, Synth esis, characterization and catalytic properties of $\mathrm{CuO}$ nanocrystals with various shapes, Nanotechnology, 17, 2006, 39393943.

[6] Wu Q H, Wei X W, Shao M W, Gu J
S, Qu M Z, Preparation of Fe-Ni alloy nanoparticles inside carbon nanotubes via wet chemistry, Chem Phys Lett, 12, 2002, 1919-1921.

[7] Yip S K, Sauls J A, Nonlinear Meissner effect in $\mathrm{CuO}$ superconductors, Physical Review Letter,_69(15),1992, 2264-2267

[8] Kim Y S, Hwang I S, Kim S J, lee C $\mathrm{Y}$, Lee $\mathrm{J} \mathrm{H}, \mathrm{CuO}$ nanowire gas sensors for air quality control in automotive cabin, Sensors and Actuators B: Chemical, 135, 2008, 298-303.

[9] Umar A, Rahman M M, Hajry A Al, Hahn Y B, Enzymatic glucose biosensor based on flower-shaped copper oxide nanostructures composed of thin Nano sheets, Electrochemistry. Communications, 11, 2009, 278-281.

[10] Yang S, Wang C, Chen L, Chen S, Facile dicyandiamide-mediated fabrication ofwell-defined $\mathrm{CuO}$ hollow microspheres and their c atalytic application, Materials $\mathrm{C}$ hemistry and Physics,120,2010,2 96-301.

[11] Borkow G, Zatcoff R C, Gavia J, Putting copper into action: copp er-impregnate-d products with potent biocidal activities, Medical Hypotheses, 9,2009, 4. 
[12] Raja Naika H, Green synthesis of $\mathrm{CuO}$ nanoparticles using Glorios a superba extract and their anti-b acterial activity, Journal of Taiba h University for Science, 9, 2015, 7-12.

[13] Borkow G, Zatcoff R C, Gabbay J, Reducing the risk of skin pathologies in diabetics by using copper impregnated socks, Medical Hypotheses, 73,2009, 883-886.

[14] Vellora V, Padil T, Cerník M, Green synthesis of copper oxide nanoparticles using gum karaya as a bio template and their antibacterial application, International Journal of Nanomedicine, 8,2013, 889-898.

[15] Singh A V, Patil R, Anand A, Milani P, Gade W N, Biological synthesis of copper oxide nanoparticles using E.coli, Current Nanoscience, 6, 2010, 365-369.

[16] Rahman A, Ismail A, Jumbianti D, Magdalena, Sudrajat H, Synthesis of Copper oxide nano particles by using Phormidium Cyanobacterium, Indonesian Journal of Chemistry, 9, 2009, $355-360$.

[17] Honary S, Barabadi H, Fathabad E G, Naghibi F, Green synthesis of copper oxide nanoparticles using
Penicillium aurantiogriseum, Pen icillium citrinum and cenicillium. Digest Journal of Nanomaterials and Biostructures, 7, 2012, 9991005 .

[18] Sankar R. et al, Green synthesis of colloidal copper oxide nanoparticles using Carica papaya and its application in photocatalytic dye degradation, Spectrochimica Acta Part A: Molecular and Biomolecular Spectroscopy, 121,2014, 746-750.

[19] Gunalan S, Sivaraj R, Venckatesh R, Aloe barbadensis Miller mediated green synthesis of Mono disperse copper oxide nanoparticles: optical properties, Spectrochimica Acta Part A: Molecular and Biomolecular Spectroscopy, 97, 2012, 11401144.

[20] Devi H S, Singh T D, Synthesis of Copper Oxide Nanoparticles by a Novel Method and its Applicat ion in the Degradation of Methyl Orange, Advance in Electronic a nd Electric Engineering, 2014. 388.

[21] Awwad A M, Albiss B A, Salem N M, Antibacterial Activity of synthesized Copper Oxide Nanopa rticles using Malva sylvestris Leaf 
Extract, SMU Medical Journal, 2, 2015, 91-100.

[22] Jafarirad S, Mehrabi M, Pur E R, Biological Synthesis of Zinc Oxi de and Copper Oxide Nanopartic les. International Conference on Chemistry, Biomedical and Envir onment Engineering, 2014, 62-64.

[23] Bauer A W, Kirby W M, Scherris J C, Truck, M, Antibiotic susceptibility testing by a standardized single disc method, The American Journal of Clinical Pathology, 36,1996, 493-496.

[24] Gupta, S.K. Handbook of practical and Clinical Immunology, $3^{\text {rd }} \mathrm{Ed}$; CBS Publishers \& Distributors: New Delhi, India, 2002, 299-300.

[25] Rajkapoor B, Jayakar B, Muruges h N. Antitumour activity of Bauh inia variegata on Dalton's Ascitic lymphoma Journal of Ethn opharmacology, 89, 2003, 107-109.

[26] Vijay Kumar P P N, Shameem U, Pratap K, Kalyani R L, Pammi S V $\mathrm{N}$, Green Synthesis of Copper O xide Nanoparticles Using Aloe vera Leaf Extract and Its antiba cterial activity against fish bacte rial pathogens, Bionanoscience, 5, 2015, 135-139.

[27] Altikatoglu M, Attar A, Erci F, Cristache C M, Isildak I, Green synthesis of copper oxide nanoparticles using Ocimum basilicum extract and their antibacterial activity, Fresenius Environmental Bulletin, 26,2017, 7832-7837.

[28] Ijaz F, Shahid S, Khan S A, Ahmad W, Zaman S, Green synthesis of copper oxide nanoparticles using Abutilon indicum leaf extract Antimicrobial, antioxidant and photocatalytic dye degradation activities, Tropical Journal of Pharmaceutical Research,16, 2017, 743-753.

[29] Ren G et al, Characterisation of copper oxide nanoparticles for antimicrobial applications, International Journal of Antimicrobial Agents, 33, 2009, 587-590.

[30] Yallappa $\mathrm{S}$ et al, Microwave assisted rapid synthesis and biological evaluation of stable copper nanoparticles using $T$. arjuna bark extract, Spectrochimica Acta, Part A: Molecular and Biomolecular Spectroscopy, 110, 2013, 108-115.

[31] Hamouda $\mathrm{T}$ et al, A novel surfactant Nano emulsion with a unique non-irritant topical antimicrobial activity against 
bacteria, enveloped viruses and fungi, Microbiological Research, 156, 2001, 1-7.

[32] Dibrov P, Dzioba J, Gosink KK, Hase C C, Chemiosmotic mechanism of antimicrobial activity of $\mathrm{Ag}^{(+)}$in Vibrio cholera, Antimicrobial Agents and Chemotherapy, 46(8), 2002, 26682670.

[33] Prasannaraj G, Venkatachalam P, Green engineering of biomoleculecoated metallic silver nanoparticles and their potential cytotoxic activity against cancer cell lines, Advances in Natural Sciences: Nanoscience and Nanotechnology, 8, 2017, 025001 .

[34] Ebraminezhad A, Bagheri M, Taghizadeh SM, Berenjian A, Ghasemi Y, Biomimetic synthesis of silver nanoparticles using micro algal secretory carbohydrates as a novel anticancer and antimicrobial, Advances in Natural Sciences: Nanoscience and Nanotechnology, 7, 2016, 015018. 